\title{
REDESAIN KEMASAN, SEBUAH USULAN BAGI UKM MITRA USAHA SANGKAR SIDOARJO
}

\author{
Yunanto Tri Laksono ${ }^{*}$, Siswo Martono ${ }^{2}$, Ardian Jaya Prasetya ${ }^{3}$ \\ 1,2 Universitas Dinamika, Jl. Raya Kedung Baruk 98, Surabaya 60298 \\ 3UPN “Veteran” Jawa Timur, Jl. Rungkut Madya No.1, Gunung Anyar, Surabaya 60294 \\ Email: 1yunanto@dinamika.ac.id, ${ }^{2}$ siswo@dinamika.ac.id, ${ }^{3}$ dio@gmail.com \\ *Penulis korespondensi
}

\begin{abstract}
Abstrak: Kelompok UKM Mitra Usaha Sangkar Kelurahan Sepanjang Kecamatan Taman Kabupaten Sidoarjo memiliki potensi unggul dalam menciptakan dan mengembangkan bentuk sangkar. Namun bentuk dan karakter desain masih bersifat manual dan masih menggunakan cara konvensional, sehingga sebagai upaya peningkatan penjualan belum mampu bersaing dan berkompetisi secara global. Mitra pada pengabdian masyarakat ini merupakan pengrajin sangkar di Kelurahan Sepanjang Kecamatan Taman Kabupaten Sidoarjo, proses pelaksanaan kegiatan terbagi dalam 3 bentuk, yaitu: persiapan, pelaksanaan, dan juga evaluasi. Peran optimalisasi dilakukan dengan bentuk survei lapangan untuk mengetahui kondisi terkait dengan proses dan sistem kerja yang dilakukan oleh pengrajin sangkar di Kelurahan Sepanjang Kecamatan Taman Kabupaten Sidoarjo. Program pengabdian masyarakat ini memiliki tujuan sebagai pengembangan masyakarat agar memiliki kemandirian dan kemapanan secara ekonomi. Melalui karya seni dalam bentuk desain produk diharapkan mampu memberikan implementasi dalam bentuk Hak Kekayaan Intelektual (HKI) yaitu desain produk industri. Melalui program kegiatan pengabdian masyarakat ini diharapkan mampu memberikan kontribusi yang baik dengan perkembangan usaha yang dimiliki oleh mitra sehingga dikemudian hari dapat memberikan continued effort pada bidang yang sama.
\end{abstract}

Kata kunci: Redesain Kemasan, konvensional, UKM Mitra Usaha Sangkar Sidoarjo.

\begin{abstract}
The SME Business Partners Sangkar in Sepanjang Village, Taman Subdistrict, Sidoarjo City has greater potential in the creation and development of cage shapes. But the form and character of the design are always manual and still using conventional systems, so in an effort to increase sales, they have not been able to compete globally. The partners in this community service are cage workers in the village of Sepanjang, Taman Subdistrict, Sidoarjo City, the process for carrying out activities is divided into three forms: preparation, implementation and evaluation. The role of optimization is carried out in the form of a field survey to find out the conditions related to the process and work system carried out by cage craftsmen in Sepanjang Village, Taman Subdistrict, Sidoarjo City. The community services program focuses on community development to ensure independence and economic stability. Thanks to the Community Service Program, it is hoped that it will be able to make a good contribution to the development of businesses owned by partners so that in the future they can provide continued efforts in the same field.
\end{abstract}

Keywords: Redesign Packaging, Conventional, SME Business Partners Sangkar Sidoarjo.

\section{PENDAHULUAN}

Produksi usaha kecil, usaha menengah, dan usaha besar di daerah sangat dibutuhkan guna menunjang hasil-hasil produk yang lebih relevan dan mampu untuk berkompetisi dalam perdagangan secara global. Usaha kecil dan menengah (UKM) adalah sebuah usaha yang melakukan kegiatan jual beli kembali (Santoso, 2017). Usaha kecil dan usaha menengah sangat dibutuhkan terkait dengan nawacita pembangunan nasional berbasis pada pengembangan ekonomi masyarakat kecil di daerah. Selain berperan dalam pertumbuhan ekonomi dan membuka lapangan kerja, UKM juga berperan dalam pendistribusian hasil-hasil pembangunan yang sesuai dengan kepentingan rakyat dan mencapai pertumbuhan ekonomi yang maksimum (Rahman, 2013). Peningkatan secara signifikan ditengarai mampu menjadikan pergeseran dalam upaya menopang peningkatan ekonomi masyakarat, data kementerian koperasi dan UKM (Bandung, 2017), prosentase signifikasi pertumbuhan ekonomi, sekitar 13,98\% unit usaha yang memiliki perkembangan sejumlah 7.716 .680 unit 
bidang usaha, yang muncul pada tahun 2012 sampai dengan pada tahun 2017.

Disisi lain pada sumber ketenagakerjaan memiliki signifikasi prosentase pada tenaga kerja sejumlah $4,96 \%$ dan simpulan jumlah tenaga kerja 15.646.504 tenaga kerja aktif peridoe 2012 sampai dengan 2017. Pengembangan dan pemanfaatan sumber daya alam telah banyak dilakukan, baik bersumber dari pengambilan secara langsung di alam seperti: pohon dan tanaman lainnya, namun hasil pengolahan yang bersumber langsung dari alam secara pengolahan belum mampu dioptimalkan dengan baik. Analisis data Berdasarkan sumber data badan statistik daerah Sidoarjo Tahun 2018, terdapat koperasi industri kerajinan (KOPINKRA) yang dikembangkan baik secara mandiri maupun kelembagaan, adapun prosentase jumlahnya adalah jumlah koperasi sebanyak 5, jumlah anggota sebanyak 460, jumlah modal sendiri/mandiri sebanyak 1.460.728, dan jumlah volume usaha sebanyak 1.030.850 (BPS Sidoarjo 2018). Hal ini juga ditunjang dengan target yang di prioritaskan oleh Pemerintah Kabupaten Sidoarjo melalui indikator pencapaian penurunan tingkat kemiskinan dengan prosentase sebesar 6,35\% pada tahun 2020, pengangguran 5,37\% pada tahun 2020 , desa mandiri $40,37 \%$ pada tahun 2020 , serta indeks pembangunan manusia sebesar $79,96 \%$ pada tahun 2020 (Statistik, 2019).

Kelurahan Sepanjang Kecamatan Taman Kabupaten Sidoarjo merupakan salah satu sentra UKM yang bergerak dalam bidang pembuatan atau pengrajin sangkar, aksesosris sangkar serta makanan burung. Namun berbagai macam kinerja yang nyata yang berasal dari usaha-usaha bersifat mikro, kecil, dan makro belum mampu untuk mendongkrak dan menopang hasil dari kualitas produksi. Disisi lain berkaitan dengan upaya peningkatan haruslah mampu ditunjang dengan upah yang disesuaikan, rendahnya upah yang diberikan menjadikan kualitas maupun hasil yang diciptakan tidak mampu menopang sebagai upaya penigkatan kualitas produksi. Bentuk pembuatan desain dan motif yang dilakukan oleh ukm pengrajin sangkar di Kelurahan Sepanjang masih menggunakan cara manual dan belum melibatkan ahli yang diharapkan melalui desain yang unggul dapat mengangkat hasil produksi. Berikut merupakan contoh corak dan motif sangkar yang ada di Kelurahan Sidoarjo, seperti tabel 1.

Beberapa faktor penyebab munculnya permasalahan UKM pengrajin sangkar di Kelurahan Sepanjang, Kecamatan Taman, Kabupaten Sidoarjo, adalah masih rendahnya pengetahuan, informasi, serta penguasaan teknologi khususnya yang berkaitan dengan desain, manajemen pemasaran serta konsep pemasaran berbasis digital. Disisi lain proses pengembangan UKM kearah yang lebih tinggi secara parsial belum mampu membawa kepada peningkatan kesejahteraan yang dimiliki oleh pengrajin sangkar di Kelurahan Sepanjang, Kecamatan Taman, Kabupaten Sidoarjo. Hal inilah yang menjadikan produk sangkar, aksesoris dan juga pakan burung tidak mampu berkonstentasi dengan produsen-produsen lainnya. Dengan adanya peningkatan produktifikas UKM seyogyanya akan mampu memiliki dampak yang cukup luas dimana nantinya akan dapat dimaksimalkan peran serta dari masyarakat di sekitar wilayah produksi.

Permasalahan pada UKM pengrajin sangkar di Keluarahan di Kelurahan Sepanjang, Kecamatan Taman, Kabupaten Sidoarjo dapat dipaparkan sebagai berikut:

a. Fungsi aksesoris secara spesifik belum mampu menarik loyalitas konsumen.

b. Motif sangkar masih terpaku dengan produkproduk sangkar lain yang ada, dan belum mempunyai identitas khusus.

Tabel 1. Motif sangkar, aksesoris dan produk makanan.

\begin{tabular}{lll}
\hline No. Nama Sangkar & Gambar & Uraian \\
\hline 1. Sangkar & $\begin{array}{l}\text { Motif serta bentuk desain sangkar masih sangat } \\
\text { sederhana dan tidak memiliki motif dan berciri khas } \\
\text { tertentu. }\end{array}$ \\
\hline 2. Aksesoris & $\begin{array}{l}\text { Menilik permintaan pasar, berkaitan dengan produk } \\
\text { aksesoris sangkar, inonasi kebaruan dalam bentuk } \\
\text { aksesoris dibutuhkan guna menungang produksi } \\
\text { sangkar yang banyak. }\end{array}$ & \\
\hline
\end{tabular}


Tabel 2. Permasalahan Mita

\begin{tabular}{|c|c|}
\hline \multicolumn{2}{|r|}{ Desain } \\
\hline $\begin{array}{c}\text { Permasalahan yang } \\
\text { dihadapi }\end{array}$ & Dampak \\
\hline Packaging/ Kemasan & $\begin{array}{l}\text { Belum adanya loyalitas pada } \\
\text { merk dan juga kemasan, yang } \\
\text { memberikan fanatisme } \\
\text { konsumen pada sebuah produk. }\end{array}$ \\
\hline Media & $\begin{array}{l}\text { Kualitas dari kemasan produk } \\
\text { yang harus disesuaikan dengan } \\
\text { kebutuhan pasar. }\end{array}$ \\
\hline Identifikasi & $\begin{array}{l}\text { Hal ini sangat diperlukan untuk } \\
\text { mengetahui produk yang } \\
\text { dihasilkan dengan produk yang } \\
\text { ada dipasaran }\end{array}$ \\
\hline \multicolumn{2}{|r|}{ Produksi } \\
\hline $\begin{array}{c}\text { Permasalahan yang } \\
\text { dihadapi }\end{array}$ & Dampak \\
\hline Bahan Baku & $\begin{array}{l}\text { Terbatasnya bahan baku utama } \\
\text { sebagai media penunjang dalam } \\
\text { pembuatan sangkar. }\end{array}$ \\
\hline Pengrajin Sangkar & $\begin{array}{l}\text { Berkurangnya pengrajin dalam } \\
\text { membuat sangkar dan } \\
\text { aksesosris khususnya di } \\
\text { Kelurahan Sepanjang. }\end{array}$ \\
\hline Competitiveness & $\begin{array}{l}\text { Persaingan yang semakin } \\
\text { kompetitif berkaitan dengan } \\
\text { produk sangkar dan asesoris } \\
\text { sangkar. }\end{array}$ \\
\hline Penjualan & $\begin{array}{l}\text { Harga pabrikan yang lebih } \\
\text { murah dengan proses } \\
\text { pendistribusian yang modern. }\end{array}$ \\
\hline Dukungan & $\begin{array}{l}\text { Minimnya dukungan } \\
\text { pemerintah sebagai pemangku } \\
\text { kepentingan dalam } \\
\text { pengembangan ukm dan umkm. }\end{array}$ \\
\hline
\end{tabular}

\section{METODE PELAKSANAAN}

Metode pelaksanaan dimaksudkan sebagai landasan utama dalam pelaksanaan program pengabdian kepada masyarakat agar implementasi kegiatan lebih terstruktur, sistematis dan juga lebih terarah. Implementasi, identifikasi permasalahan pada saat observasi sangat penting dilakukan secara cermat sehingga memberikan daya dukung dalam melakukan perancangan kegiatan terkait solusi permasalahan.

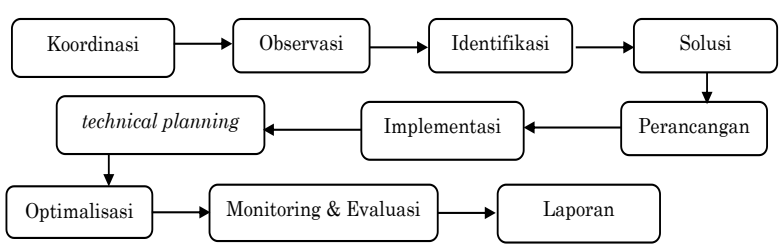

Gambar 1. Bagan Alur Pelaksanaan Program.

Koordinasi adalah suatu usaha kerja sama antara badan, instansi, unit, dalam pelaksanaan tugas-tugas tertentu sedemikian rupa, sehingga terdapat saling mengisi, saling membantu, dan saling melengkapi (Hasibuan, 2011). Pelaksanaan koordinasi dan observasi dengan mitra mencakup aspek kapasitas, kapabilitas, kualitas, legalitas, kredibilitas, dukungan dalam bentuk sumber daya alam, dukungan dalam bentuk sumber daya manusia, sarana prasarana dan relevansi dengan permasalahan. Sementara proses penyampaian informasi secara baik, sesuai prosedur, tepat, dan pembagian sistem kerja yang adaptif dengan pelaksanaan koordinasi akan mampu mengoptimalkan hasil sesuai tenggat waktu yang disepakati. Sementara proses identifikasi yang dipilih haruslah berdasarkan tujuan yang ingin dicapai. Prosedur identifikasi haruslah berdasarkan hal-hal dan tujuan program yang bisa dipertahankan (Linden, 2002). Prinsip identifikasi meliputi hal-hal sebagai berikut:

a. Metode identifikasi haruslah dipilih konsisten dengan definisi.

b. Prosedur identifikasi haruslah bervariasi.

c. Prosedur untuk identifikasi harus baku dan konsisten.

d. Jika ada keterbatasan dalam lingkungan, maka kita harus mempertimbangkan apa yang dapat dilakukan dalam lingkungan tertentu (Hawadi, 2002).

Hasil dari proses identifikasi yang dilakukan, maka diperoleh sesuai data dalam gambar 2 .

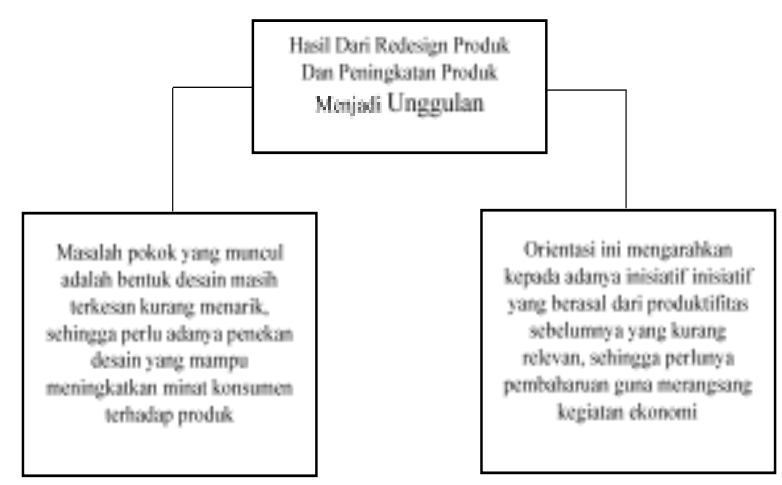

Gamar 2. Identifikasi Produk

Sedangkan problem solving adalah proses ilmiah seseorang yang melalui sebuah fase dari pemahaman masalah untuk kemudian mencari informasi yang diperlukan untuk diputuskan solusi pemecahannya dan dievaluasi solusinya. Artinya bahwa seseorang yang menghadapi suatu masalah harus mencari sumber informasi dari akar permasalahan tersebut terlebih dahulu. Sehingga seseorang itu akan dengan mudah memutuskan sebuah solusi yang akan dipakainya dalam memecahkan suatu masalah (Guven, 2016). "Packaging involves designing and producing the container or wrapper for a product" yang artinya adalah proses kemasan melibatkan kegiatan mendesain dan memproduksi, fungsi utama dari kemasan sendiri yaitu melindungi produk agar produk tetap terjaga kualitasnya (Amstrong, 2012). Kemasan mempunyai tujuan dan fungsi dalam pembuatan produk, yaitu: 
a. Memperindah produk dengan kemasan yang sesuai kategori produk;

b. Memberikan keamanan produk agar tidak rusak saat dipajang di toko;

c. Memberikan keamanan produk pada saat pendistribusian produk;

d. Memberikan informasi pada konsumen tentang produk itu sendiri dalam bentuk pelabelan;

e. Merupakan hasil desain produk yang menunjukkan produk tersebut (Wijayanti, 2012).

f. Kemasan yang baik dapat membangun ekuitas merek dan mendorong penjualan.

Beberapa faktor yang memiliki kontribusi penggunaan kemasan alat pemasaran:

a. Swalayan, kemasan yang efektif melaksanakan tugas dalam penjualan: menarik perhatian, menggambarkan fitur produk, menciptakan keyakinan konsumen, dan membuat kesan menyenangkan.

b. Kekayaan Konsumen, peningkatan kekayaan konsumen membuat mereka bersedia membayar lebih besar untuk kenyamanan, penampilan, keandalan, dan gengsi kemasan yang lebih baik.

c. Perusahaan dan Citra Merek, kemasan mempunyai peran terhadap pengakuan segera atas perusahan atau merek.

d. Peluang inovasi, kemasan yang inovatif dapat membawa manfaat besar bagi konsumen dan laba bagi para produsen (Keller, 2012).

Implementasi secara eksplisit mencakup tindakan tindakan oleh individu/kelompok privat (swasta) dan publik yang langsung pada pencapaian serangkaian tujuan terus menerus dalam keputusan kebijakan yang telah ditetapkan sebelumnya (Taufik, 2013).

Beberapa tahapan metode pelaksanaan seperti paparan di atas digunakan dalam mencermati permasalahan dan mengupayakan solusinya bersama mitra perajin sangkar.

\section{HASIL DAN PEMBAHASAN}

Produksi sangkar burung merupakan salah satu industri yang mampu dikaryakan berkonsep industri rumahan maupun industri besar, karena sangkar memiliki potensi yang cukup menjanjikan khususnya di Indonesia. Banyak pengrajin kecil maupun pengrajin besar berlomba-lomba untuk mengembangkan kerajinan sangkar, melaui bentuk, motif, ornamen berupaya diciptakan untuk menarik minat konsumen. Banyaknya komunitas pecinta burung, area perlombaan yang secara pemakaian menginginkan produk yang memiliki perbedaan sehingga tampilan sangkar yang dipakai memiliki ciri khas tertentu sehingga tampilan lebih menarik.disisi lain banyaknya budidaya dan penangkaran burung yang cukup besar menjadikan sentra industri pengrajin sangkar memiliki banyak pesanan. Tersedianya bahan mentah dan juga keuletan serta ketelitian dari pengrajin menjadikan sangkar begitu banyak di minati oleh konsumen.

Setelah melalui proses diskusi, sharing dan pemantauan di lapangan bersama mitra, diketahui bahwa desain sangkar yang konvensional harus dirubah ke arah desain yang mengikuti selera pasar. Pemahaman ini menjadi modall dasar bagi perajin sangkar untuk mengembangkan produk dan meningkatkan hasil produksi melalui desain produk yang lebih menarik dan diminati oleh konsumen sehingga mampu meningkatkan taraf ekonomi masyarakat pengrajin sangkar di Kelurahan Sepanjang, Kecamatan Taman, Kabupaten Sidoarjo.

Temuan lain di lapangan adalah hasil olahan sangkar menghasilkan limbah yang belum mampu dimanfaatkan dengan baik. Hal ini terjadi karena kemampuan perajin sangkar masih sangat rendah dan belum mampu memberikan hasil produksi yang maksimal. Artinya pengrajin sangkar burung belum mampu memaksimalkan pemanfaatan input atau kemampuannya dengan baik sehingga tidak dapat mencapai bagian efisiensi dari produksi. Hasil pendapatan yang berasal dari penjualan juga sangkar juga belum dioptimalkan untuk pengembangan produk. Sebenarnya desain sangkar yang menarik dan bernilai jual memiliki kontribusi sebagai alat pemasaran, seperti disampaikan oleh Keller:

a. Swalayan, kemasan yang efektif melaksanakan tugas dalam penjualan: menarik perhatian, menggambarkan fitur produk, menciptakan keyakinan konsumen, dan membuat kesan menyenangkan.

b. Kekayaan Konsumen, peningkatan kekayaan konsumen membuat mereka bersedia membayar lebih besar untuk kenyamanan, penampilan, keandalan, dan gengsi kemasan yang lebih baik.

c. Perusahaan dan Citra Merek, kemasan mempunyai peran terhadap pengakuan segera atas perusahan atau merek.

d. Peluang inovasi, kemasan yang inovatif dapat membawa manfaat besar bagi konsumen dan laba bagi para produsen (Keller, 2012).

Terkait hal ini, salah satu hal utama yang dilakukan adalah peningkatan desain produk, dengan optimalisasi desain yang baru lebih mengharuskan warna yang baik dalam menunjang penjualan dan juga mampu dioptimalkan dengan kaitannya pengembangan inovasi yang bersifat kebaruan. Hal ini dilakukan dengan membuatkan motif, bentuk dan desain yang memiliki kebaruan sehingga akan menambah dan meningkatkan nilai jual pada konsumen sehingga akan memiliki daya tarik baik oleh penangkar burung maupun masyarakat yang melombakan burung. 


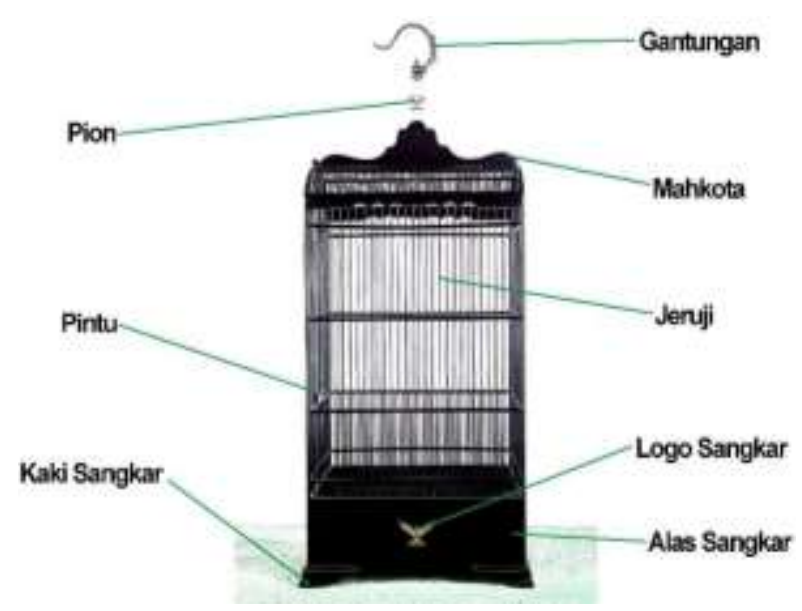

Gambar 3. Desain Sangkar

Beberapa catatan solutif dapat dijelaskan dalam tabel 3.

Tabel 3. Solusi Permasalahan

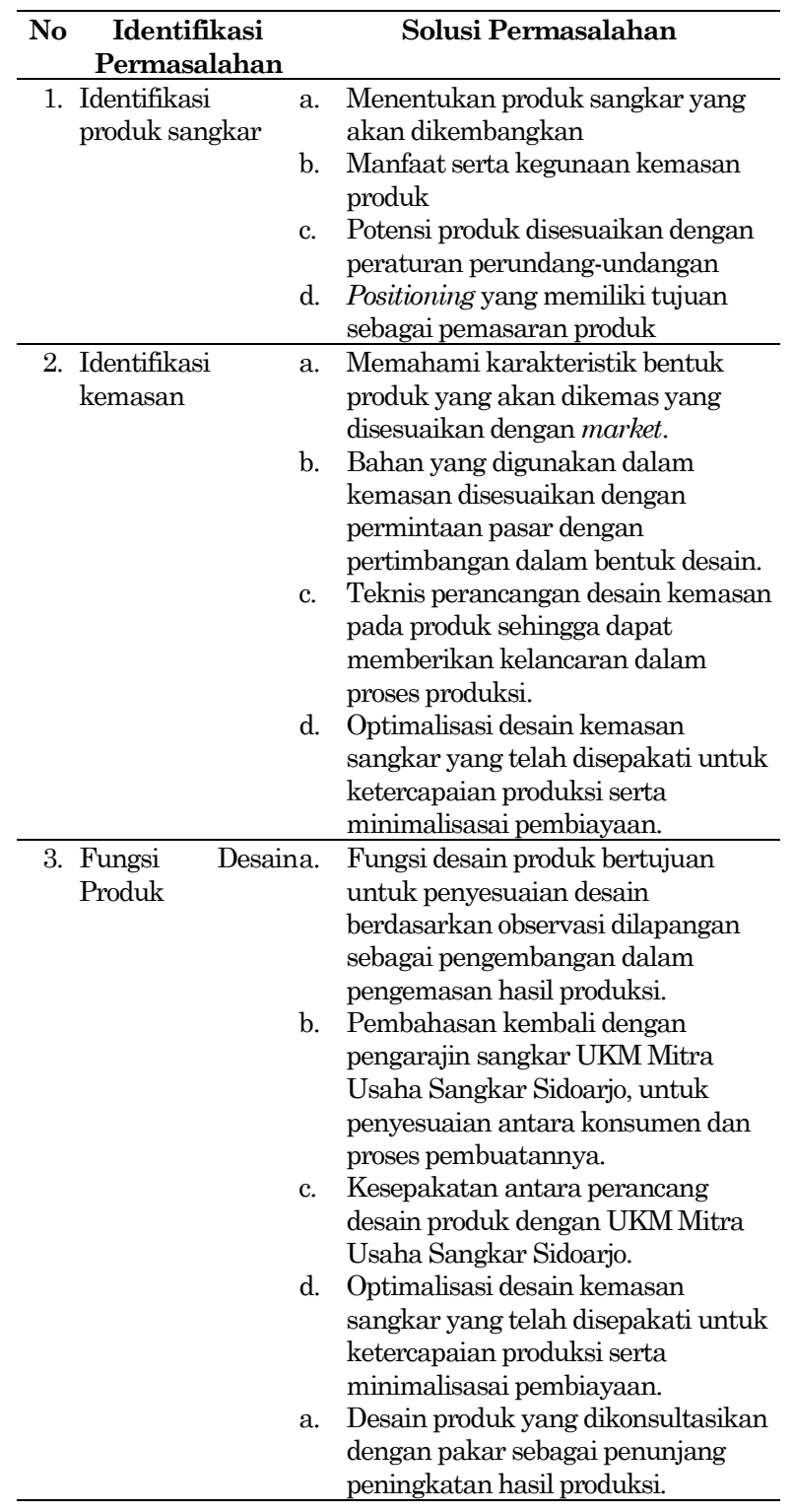

\section{Solusi}

Hasil penentuan materi dengan mitra kemudian dikumpulkan untuk dicari solusi mengenai produksi sampai pada bagian marketing produksi pada UKM. Dari proses redesain produk sampai Pembuatan produk baru akan dipilih berdasarkan kebutuhan UKM.

\section{Technical Planning}

Rencana yang akan dibuat untuk sebuah desain sangkar akan melalui beberapa tahapan dan akan merubah beberapa bentukan dari bentukan awal menjadi bentukan yang sudah dilakukan desain. Teknik desain yang akan dilakukan yaitu menyangkut beberapa bagian dalam sangkar seperti pada tabel 4 .

Tabel 4. Teknik desain bagian dalam sangkar

\begin{tabular}{clc}
\hline No. & Bagian Sangkar & Proses Redesain \\
\hline 1 & Gantungan & Minor \\
2 & Pion & Minor \\
3 & Mahkota & Mayor \\
4 & Jeruji & Minor \\
5 & Pintu & Minor \\
6 & Logo Sangkar & Mayor \\
7 & Alas Sangkar & Mayor \\
8 & Kaki Sangkar & Mayor \\
\hline
\end{tabular}

\section{Implementasi}

Proses implementasi desain merujuk pada poin-poin bagian pada sangkar yang akan dilakukan proses perubahan atau redesain. Perubahan awal dilakukan dengan menggunakan bagian produk yang sudah ada dan dilakukan bentukan desain dengan beberapa alternatif.

Tabel 5. Implementasi desain beberapa alternatif

\begin{tabular}{lcc}
\hline No. Bagian Sangkar & Proses Redesain & Bentukan awal \\
\hline 1 Gantungan & Minor & \\
\hline 2 Pion & Minor & \\
\hline 3 Mahkota & Mayor & \\
\hline 4 Jeruji & Minor
\end{tabular}




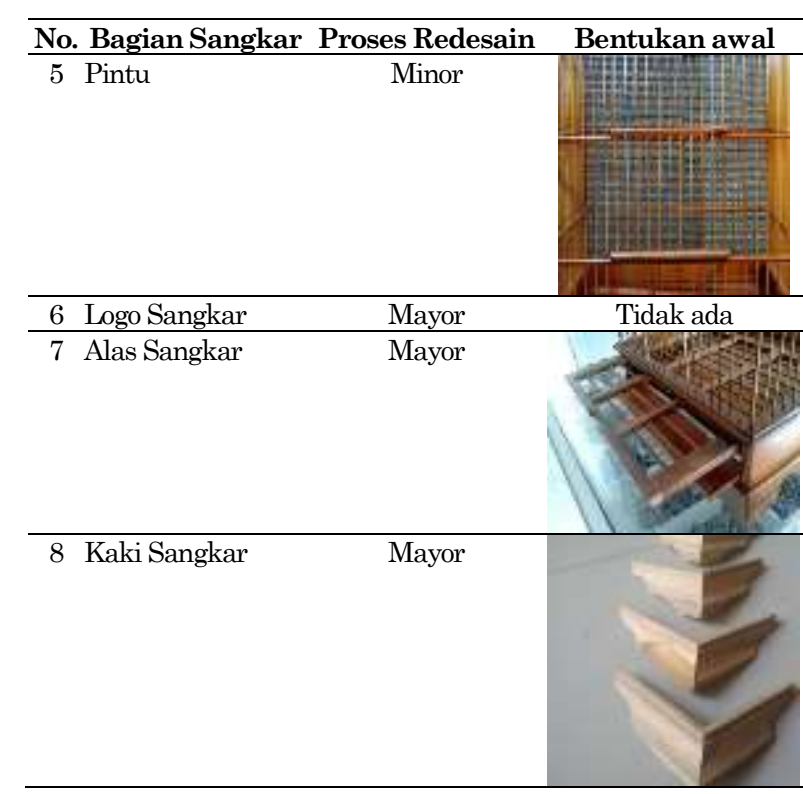

\section{Perancangan Desain}

Hasil dan implementasi berdasarkan desain dasar yang mengalami pembaharuan sehingga tampilannya lebih menarik dan memiliki nilai jual yang lebih baik.

Tabel 6. Perancangan desain sangkar

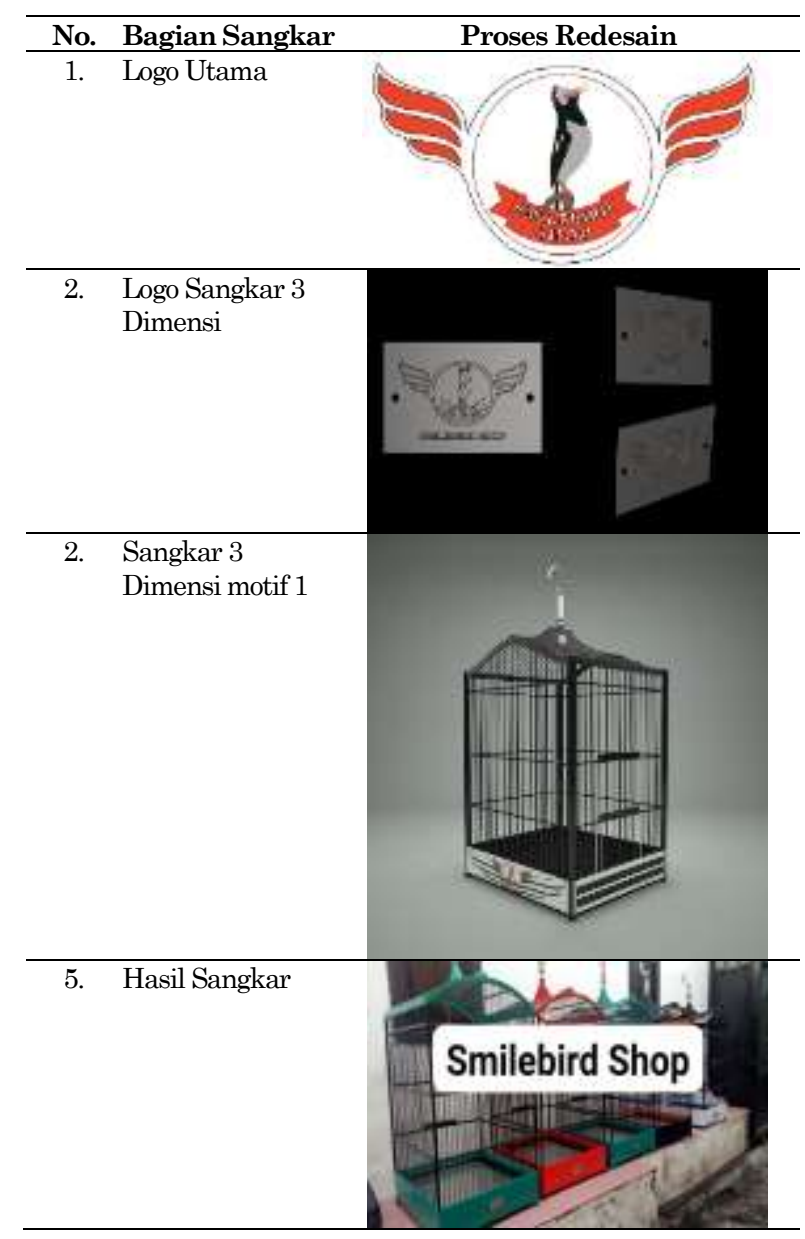

Tabel 7. Testimoni Penjualan produk Sangkar

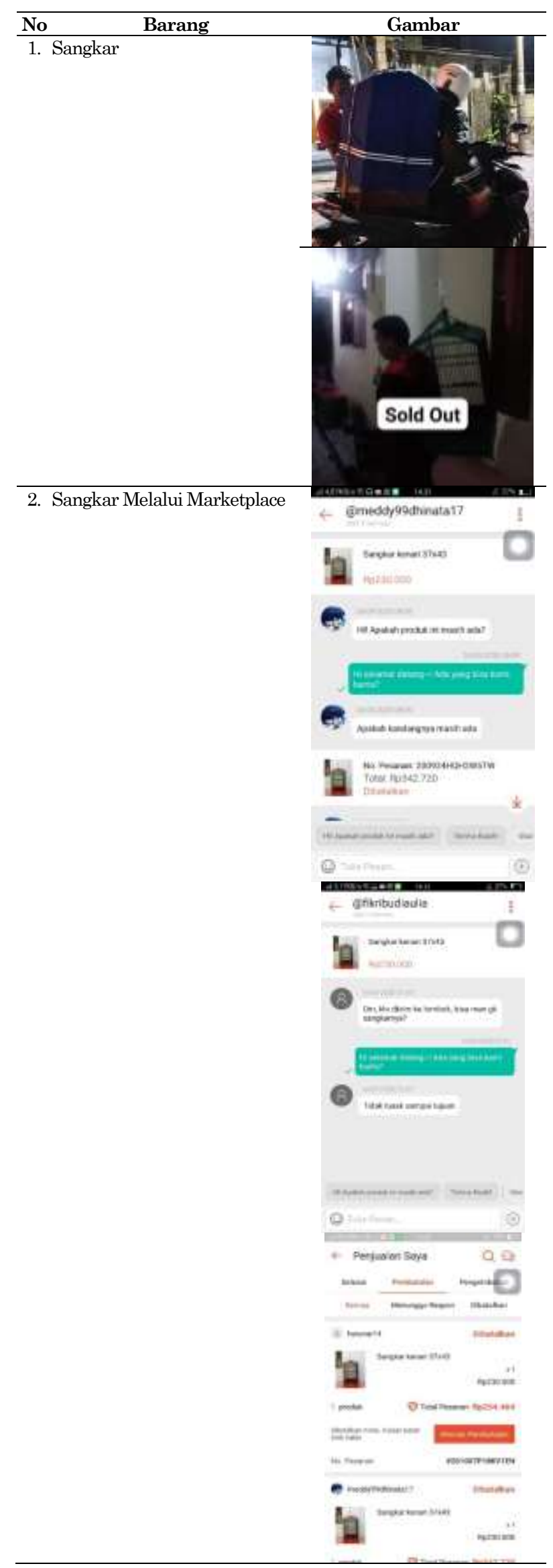




\section{SIMPULAN}

Perkembangan pada Industri Kecil dan Menengah (UKM), dan Usaha Mikro, Kecil dan Menengah (UMKM), harus mendapatkan perhatian lebih dari berbagai pihak salah satunya adalah pemangku kepentingan tertinggi yaitu pemerintah. Dengan proses pengembangan kegiatan secara manual atau tanpa adanya pendidikan secara khusus maka diperlukan pembimbingan secara masiv dan terstruktur guna meningkatkan kapasitas dan kemapuan pelaku UKM dan UMKM di daerah khususnya daerah Sidoarjo. Sehingga kedepan kegitan pengabdian kepada masyarakat haruslah lebih ditingkatkan Kembali guna menunjang kemajuan hasil-hasil produk dalam negeri guna meningkatkan taraf ekonomi masyarakat juga berpengaruh dalam meningkatkan kemajuan suatu daerah. Diharapkan melalui adanya re-desain sangkar mampu meningkatkan peran UKM dan UMKM supaya lebih produktif dan mampu lebih berinovasi dalam menghasilkan produk-produk yang berkualitas dan secara khusus mampu memiliki keunggulan. Produk-produk yang dihasilkan juga diharapkan mampu bersaing dengan produkproduk lain baik dalam negeri maupun produk di luar negeri sehingga memicu peningkatan taraf hidup masyarakat lokal.

\section{UCAPAN TERIMAKASIH}

Ucapan terima kasih kami berikan kepada seluruh pihak yang telah membantu dalam menyelesaikan artikel ini sehingga dapat dikirimkan sesuai dengan tenggat waktu yang ditentukan. Adapun ucapan terima kasih kami sampaikan kepada:

1. Terima kasih kepada Universitas Dinamika yang menerima proposal pengabdian kepada masyarakat dan menjadi fasilitator dalam mengembangkan pengabdian kepada masyarakat tahun 2020;

2. Terima kasih kepada LPPM Universitas Dinamika yang memberikan motivasi dalam penyelesaian artikel ini sehingga mampu dan dapat berkontribusi dalam pengabdian kepada masyarakat melalui artikel;

3. Terima kasih kepada perajin sangkar di Kelurahan Sepanjang Kecamatan Taman Kabupaten Sidoarjo yang bersedia menjadi mitra kami dalam program pengabdian kepada masyarakat.

\section{DAFTAR PUSTAKA}

Bandung, D. U. (2017). Statistik Usaha Mikro, Kecil dan Menengah Tahun 2008-2017. Dalam D. U. Bandung, Statistik Usaha Mikro, Kecil dan Menengah Tahun 2008-2017. Bandung: Dinas UMKM Kota Bandung.

Guven, O. d. (2016). Evaluating Students Beliefs in Problem Solving Process: A Case Study. . Eurasia Journal of Mathemathics, Science and Technology Education, 411-429.

Hasibuan, M. (2011). Manajemen Sumber Daya Manusia. Dalam M. Hasibuan, Manajemen Sumber Daya Manusia. Jakarta: Bumi Aksara.

Linden, H. H. (2002). Identification Reaction. Dalam H. H. Linden, Identification Reaction. Zurich: UoZ Press.

Rahman, A. (2013). Pengaruh Karakteristik Individu, Motivasi dan Budaya Kerja Terhadap Kinerja Pegawai Pada Badan Keluarga Berencana dan Pemberdayaan Perempuan Kabupaten Donggala. Jurnal E-Jurnal Katagolis, Volume 1 Nomor 2., 2.

Santoso, s. (2017). Menguasai Statistik Dengan SPSS 24.

Santoso, S. (2017). Metode Analisis. Dalam S. Santoso, Metode Analisis. Jakarta: PT. Alex Media Komputindo.

Statistik, B. P. (2019). Inequality Of Population Expenditure In Indonesia September 2017. Dalam B. P. Statistik, Inequality Of Population Expenditure In Indonesia September 2017. Sidoarjo: Badan Pusat Statistik Kabupaten Sidoarjo.

Taufik, A. d. (2013). Analisis Pertumbuhan Ekonomi dan Pengembangan Sektor Potensial di Kabupaten Asahan. QE Jurnal, 01-33.

Triani. (2011). Analisis Produksi Susu, Persentase Protein Susu dan Konsumsi Hijauan Sapi Fh (Fries Holland) Pada Tingkat Laktasi Yang Berbeda di Upt Ruminansia Besar Dinas Peternakan Kabupaten Kampar. Riau: Universitas Islam Negeri Sultan Syarif.

Wijayanti, T. (2012). Marketing Plan, Dalam Bisnis Second Edititon. Jakarta. Dalam Marketing Plan, Dalam Bisnis Second Edititon. Jakarta. Jakarta: PT Elex Media Komputindo. 